\title{
Author Index, Volume 77, 2001
}

Abrahamson, L.P. - See Kopp, R.F. et al.

Apentiik, C. - See MacKinnon, L. et al.

287

Apsey, T.M. - Dynamic initiatives on the sustainable forest

management journey

Armstrong, G.W.- See Cumming, S.G.

Aronsson, P. and K. Perttu. - Willow vegetation filters for wastewater treatment and soil remediation combined with biomass production

Audet, G. - See Lavallée, R. et al.

Baker, Ken. - Can forestry remain viable over the next 20 years?

Balatinecz, J.J., D.E. Kretschmann and A. Leclercq. - Achievements

in the utilization of poplar wood - guideposts for the future

Ballard, W.B. - See Sabine, D.L.

Barkley, B. and G. McVey. - The role and response of the Eastern

Ontario Model Forest to the 1998 ice storm

Beedle, B. - See Duinker, P.

Beedle, B. - See Teske, E.

Bélanger, G. - See Castonguay, M. et al.

Berguson, W.E. - See Riemenschneider, D.E. et al.

Blais, J., J.-P.L. Savard and J. Gauthier. - Impact of an ice storm

on resident bird populations in eastern North America

Blais, L. - See Roy, V. et al.

Blenis, P.V. - See MacPherson, D.M. et al.

Bonar, R.L. - Sustainable forest management practices on the

Weldwood Forest Management Area at Hinton, Alberta

Bouthillier, L. - See Côté, M.-A. et al.

Bowman, J. - See Sabine, D.L.

Boysen, E. - See Parker, W.C. et al.

Bull, G., S. Nilsson, J. Williams, E. Rametsteiner, T. Hammett

and W. Mabee. - Wood procurement policy: An analysis of critical issues and stakeholders

Burgess, D. - See Penner, M.C. et al.

Burkhardt, R. - New directions needed: Perspectives on progress

toward sustainable forest management in Canada

Burton, Philip J. - See Tittler, Rebecca et al.

Carmean, W.H., G.P. Niznowski and G. Hazenberg. - Polymorphic

site index curves for jack pine in Nothern Ontario

Castonguay, M., A. Lebeau, M.-J. Coupal, J. Pâquet et G. Bélanger.

- La tempête de verglas de 1998 : les programmes forestiers au Québec 599

Churchill, M.M. - Corner Brook Pulp and Paper Limited - Best

management practices - Harvesting

Ciesla, W.M. - See Gaoping, Wang et al.

Conlin, T.S.S. - In-woods chipping: Possible evidence for

allelochemical interaction of leachate generated from trembling aspen

(Poplus tremuloides Michx.) bark and wood waste

Corbett, C. - Sustainable forest management in Algonquin Provincial

Park

Côté, M.-A., D. Kneeshaw, L. Bouthillier and C. Messier. -

Increasing partnerships between scientists and forest managers:

Lessons from an ongoing interdisciplinary project in Québec

Coulombe, C. - See Lavallée, R. et al.

Coupal, M.-J. - See Castonguay, M. et al.

Couto, L. - See Dubè, F.

Crête, M. - See Etcheverry, P. et al.

Cumming, S.G. and G.W. Armstrong. - Divided land base and

overlapping forest tenure in Alberta, Canada: A simulation study

exploring costs of forest policy

Daoust, G. - See Lavallée, R. et al.

David, A.J., J.C. Zasada, D.W. Gilmore and S.M. Landhäusser. -

Current trends in the management of aspen and mixed aspen forest for sustainable production

de la Roche, Ian and Christopher Gaston. - The future of wood

products: What is the prognosis?

de Vries, S.M.G. - See Lefevre, F. et al.

de Vries, S.M.G. - Conservation of natural ecosystems of poplar and

willow

Dey, D.C. - See Parker, W.C. et al.

Dickmann, D.I. - See Riemenschneider, D.E. et al.

DiFazio, S.P. - See Strauss, S.H. et al.

at the beginning of the 21st century: A review

Duinker, P. and B. Beedle. - Policies and practices for sustainable

forest management in Canada

Eastin, I.L. and J. Fukada. - The impact of regulatory change on the international competitiveness of the Canadian softwood lumber industry

Elliot, K.A. - See Parker, W.C. et al.

Emerson, D. - B.C. trees: Power brand or marketing pariah

Etcheverry, P., J.-P. Ouellet, J. Maltais, M. Crête et J. Huot. -

Alimentation d'urgence de cerfs de Virginie lors d'hivers rigoureux

Rabattage de tiges non commercials versus distribution de moulée

Findlay, C. - Pilot projects under the B.C. Forest Practices Code -

a springboard for change

Forbes, G. - See Sabine, D.L.
85

885

599

817

Fox, G. - See Kidon, J. et al .

Fraser, E.C., R. Kabzems and V.J. Lieffers. - Sheep grazing for vegetation management in the northern forests British Columbia and Alberta

Fukada, J. - See Eastin, I.L

Gaoping, Wang, Yan Qing, Zhang Kai and W.M. Ciesla. - Factors affecting production of Chinese Chestnut in Xinxian County, Henan Province, China

Gaston, Christopher. - See de la Roche, Ian.

Gauthier, J. - See Blais, J. et al.

Gauthier, S. - See Hirsch, K. et al.

Gilmore, D.W. - See David, A.J. et al.

Gluck, M. - See Nilsson, S.

Gordon, J.C. - Poplars: Trees of the people, trees of the future

Greifenhagen, S. - See Hopkin, A.A. et al.

Greifenhagen, S. - See Rice, J.A. et al.

Griffin, D.H. - See Manion, P.D. et al.

Hall, Peter J. and J. Richardson - ENFOR - Energy from the forest

Hall, R.B. - See Riemenschneider, D.E. et al.

Hamann, A. - Utilization and management of red alder genetic

resources in British Columbia

Hammett, T. - See Bull, G. et al.

Han, Y. - See Weisgerber, H

Hardy, Yvan. - Forestry in Canada in 2020

Hawkes, B. - See Hirsch, K. et al.

Hazenberg, G. - See Carmean, W.H. et al.

Heinze, B.-See Lefèvre, F. et al.

Hirsch, K., V. Kafka, C. Tymstra, R. McAlpine, B. Hawkes, H.

Stagehuis, S. Quintilio, S. Gauthier and K. Peck. - Fire-smart

forest management: A pragmatic approach to sustainable forest

management in fire-dominated ecosystems

Hirvonen, H. - Canada's National Ecological Framework: An asset to reporting on the health of Canadian forests

Holland, J. - See Hopkin, A.A. et al.

Hopkin, A.A., S. Greifenhagen and J. Holland. - Decay, stains and

beetles in ice-storm-damaged forests: A review

Huot, J. - See Etcheverry, P. et al.

Isebrands, J.G. - See Riemenschneider, D.E. et al.

Isebrands, J.G.-See Kopp, R.F. et al.

Jobidon, R. - See Roy, V. et al.

Jonas, M. - See Nilsson, S. et al.

Kabzems. R. - See Fraser, E.C. et al.

Kafka, V. - See Hirsch, K. et al.

Kai, Zhang. - See Gaoping, Wang et al.

Kajba, D. - See Lefèvre, F. et al.

Kidon, J., G. Fox, D. McKenney and K. Rollins. - Economic impact of the 1998 ice storm on the eastern Ontario maple syrup industry

King, D.J. - See Olthof, I. et al.

Kneewshaw, D. - See Côté, M.-A. et al.

Kopp, R.F., L.B. Smart, C.A. Maynard, J.G. Isebrands, G.A.

- The development of improved

willow clones for eastern North America

Kretschmann, D.E. - See Balatinecz, J.J. et al.

Laberge, C. - See Zarnovican, R. et al.

Landhäusser, S.M. - See David, A.J. et al.

Landhäusser, Simon M. - See Stewart, James D. et al 1006

Lautenschlager, R.A. - Ice storm 1998 - Forest policy and research papers

Lautenschlager, R.A. - See Ter-Mikaelian, M.

Lautenschlager, R.A. and J.A. Winters. - Quantifying ice damage by counting branches on damaged sugar maple trees

Lautenschlager, R.A. - See Olthof, I. et al.

Lavallée, R., G. Daoust, Y. Mauffette, G. Audet and C. Coulombe.

- Feeding, oviposition and emergence of the white pine weevil

(Pissodes strobi (Peck)) under a pioneer broad-leaved forest canopy

Lebeau, A. - See Castonguay, M. et al.

Leclercq, A. - See Balatinecz, J.J. et al.

Lefèvre, F., D. Kajba, B. Heinze, P. Rotach, S.M.G. de Vries and

J. Turok. - Black poplar: A model for gene resource conservation in forest ecosystems

Lieffers, V.J. - See Fraser, E.C. et al.

Lieffers, V.J. - See MacPherson, D.M. et al.

Lieffers, Victor J. - See Stewart, James D. et al.

Lussier, J.-M. - See Zarnovican, R. et al.

Mabee, W. - See Bull, G. et al.

MacDonald, Blake G. - See Rice, J.A. et al.

Macknon, L., C. Apentiik and M.P. Robinson. - Revisiting raditional land use and occupancy studies: Relevance and implications for resource management in Alberta

MacPherson, D.M., V.J. Lieffers and P.V. Blenis. - Productivity of aspen stands with and without a spruce understory in Alberta's boreal mixedwood forests

Mahoney, S.P. - See McLaren, B.E.

Maltais, J. - See Etcheverry, P. et al. 
Manion, P.D., D.H. Griffin and B.D. Rubin. - Ice damage impacts on the health of the northern New York State forest

Manion, P.D. - See Rubin, B.D.

Marchak, P. - Logging the globe: The changing context for Canadian forestry

Martel, Jean-Pierre. - People, trees and forests in 2020: Is there a role for the forest industry?

Martin, P.J. - See Nigh, G.D.

Mauffette, Y. - See Saint-Germain, M.

Mauffette, Y. - See Lavallée, R. et al.

Maynard, C.A. - See Kopp, R.F. et al.

McAlpine, R. - See Hirsch, K. et al.

McKenney, D. - See Kidon, J. et al.

McKenney, D. - Economies of scale for a national research

organization: Looking for opportunities beyond the nose hairs on bears 860

McKenney, D. - Thinking about the economics of genetic resource management for Canadian forestry

McLaren, B.E. and S.P. Mahoney. - Comparison of forestry-based remote sensing methodologies to evaluate woodland caribou habitat in non-forested areas of Newfoundland

McLaughlin, J.A. - Impact of Armillaria root disease on succession in red pine plantations in southern Ontario

McVey, G. - See Barkley, B.

Meilan, R. - See Strauss, S.H. et al.

Messier, C. - See Côté, M.-A. et al.

Messier, Christian. - See Tittler, Rebecca et al.

Mihajlovich, Milo. - Does forest certification assure sustainability? - A case study

Mohn, C.A. - See Riemenschneider, D.E. et al.

Moores, L.J. - See Nazir, M.

Morgenstern, E.K. and B.S.P. Wang. - Trends in forest depletion, seed supply, and reforestation in Canada during the past four decades Myers, H. - From fur to fir: Lessons for the BC forest industry from the anti-fur campaign

Nazir, M. - Future forest policies in Canada

Nazir, M. and L.J. Moores. - Forest policy in Newfoundland and Labrador

Newmaster, S.G. - See Parker, W.C. et al.

Nigh, G.D. and P.J. Martin. - A method to assess the performance of growth intercept models in British Columbia

Nilsson, S., M. Jonas, M. Obersteiner and D.G. Victor.

Verification: The gorilla in the struggle to slow global warming

Nilsson, S. and M. Gluck. - Sustainability and the Canadian forest sector

Nilsson, S. - See Bull, G. et al.

Niznowski, G.P. - See Carmean, W.H. et al.

Obersteiner, M. - See Nilsson, S. et al.

Oliver, Chadwick D. - Policies and practices: Options for pursuing forest sustainability

Olthof, I., D.J. King and R.A. Lautenschlager. - Leaf area index

change in ice-storm-damaged sugar maple stands

Ouellet, J.-P. - See Etcheverry, P. et al.

Paillé, G. - Les grands enjeux de l'amenagement forestier durable au Québec

Paillé, G. - Major issues facing sustainable forest management in Quebec 459

Pâquet, J. - See Castonguay, M. et al.

Parker, W.C., K.A. Elliot, D.C. Dey, E. Boysen and S.G.

Newmaster. - Managing succession in conifer plantations: converting young red pine (Pinus resinosa Ait.) plantations to native forest types by thinning and underplanting

Peck, S. - See Hirsch, K. et al.

Penner, M., C. Robinson and M. Woods. - The response of good and poor aspen clones to thinning

Penner, M., C. Robinson and D. Burgess. - Pinus resinosa product

potential following initial spacing and subsequent thinning

Perttu, K. - See Aronsson, P

Pitt, D., D. Weingartner and S. Greifenhagen. - Precommercial thinning of trembling aspen in northern Ontario: Part 2 - Interactions with Hypoxylon canker

Pitus, O.T. - See Vlosky, R.P.

Pulkki, R. - Forest harvesting operations in South Africa

Qing, Yan. - See Gaoping, Wang et al.

Quintilio, S. - See Hirsch, K. et al.

Rametsteiner, E. - See Bull, G. et al.

Rice, J.A., G. Blake MacDonald and D.H. Weingartner. -

Precommercial thinning of trembling aspen in northern Ontario:

Part 1 - Growth responses

Richardson, J. - See Hall, Peter J.

Riemenschneider, D.E., W.E. Berguson, D.I. Dickmann, R.B.

Hall, J.G. Isebrands, C.A. Mohn, G.R. Stanosz and G.A. Tuskan.

- Poplar breeding and testing strategies in the north-central U.S.:

Demonstration of potential yield and consideration of future needs

Roberts, Ralph E. and John Roper. - An international forestry

organization: Do we need one?

Robinson, C. - See Penner, M.C. et al.
Robinson, C. - See Penner, M. et al.

Robinson, M.P. - See MacKinnon, L. et al. 479

Rollins, K. - See Kidon, J. et al. 667

Roper, John. - See Roberts, Ralph E.

Rotach, P. - See Lefèvre, F. et al.

Roy, V., R. Jobidon et L. Blais. - Étude des facteurs asociés au

dépérissement du bouleau à papier en peuplement résiduel après coupe 509

Rubin, B.D. and Manion, P.D. - Landscape-scale forest structure in northern New York and potential successional impacts of the 1998

ice storm

Rubin, B.D. - See Manion, P.D. et al.

Ryall, K.L. and S.M. Smith. - Bark and wood-boring beetle response in red pine (Pinus resinosa Ait.) plantations damaged by the 1998 ice storm: Preliminary observations

Sabine, D.L., W.B. Ballard, G. Forbes, J. Bowman and H.

Whitlaw. - Use of mixedwood stands by wintering white-tailed deer in southern New Brunswick

Saint-Germain, M. and Y. Mauffette. - Reduced ground beetle activity following ice damage in maple stands of southwestern Quebec 65

Savard, J.-P.L. - See Blais, J. et al.

Sedjo, R.A. - The role of forest plantations in the world's future timber supply

Smart, L.B. - See Kopp, R.F. et al.

Smith, S.M. - See Ryall, K.L.

Stadt, Kenneth J. - See Stewart, James D. et al.

Stagehuis, H. - See Hirsch, K. et al.

Stanosz, G.R. - See Riemenschneider, D.E. et al.

Stennes, B. - See Wilson. B. et al.

Stewart, James D., Simon M. Landhäusser, Kenneth J. Stadt and

Victor J. Lieffers. - Predicting natural regeneration of white spruce

in boreal mixedwood understories

Strauss, S.H., S.P. DiFazio and R. Meilan. - Genetically modified poplars in context

Takahashi, T. - See Wilson, B. et al.

Ter-Mikaelian, M. and Lautenschlager, R.A. - Predictive equations

for leaf area and biomass for sugar bushes in eastern Ontario

Teske, E. and B. Beedle. - Journey to the top - breaking through the

canopy: Canadian experiences

Tindall, D.B. - Social science and forestry curricula: Some survey results

Tittler, Rebecca, Christian Messier and Philip J. Burton. -

Hierarchical forest management planning and sustainable forest

management in the boreal forest

Tomsons, S. - Western ethics and resource management: A glance

at the history

Turok, J. - See Lefèvre, F. et al.

Tuskan, G.A. - See Riemenschneider, D.E. et al.

Tuskan, G.A. - See Kopp, R.F. et al.

Tuskan, G.A. and M.E. Walsh. - Short-rotation woody crop systems, atmospheric carbon dioxide and carbon management: A U.S. case study

Tymstra, C. - See Hirsch, K. et al.

Vertinsky, I. - See Wilson, B. et al.

Verwijst, T. - Willows: An underestimated resource for environment

and society

Victor, D.G. - See Nilsson, S. et al.

Vlosky, R.P. and O.T. Pitus. - eBusiness in the forest products

industry: A comparison of the United States and Canada

Walsh, M.E. - See Tuskan, G.A.

Wang, B.S.P. - See Morgenstern, E.K.

Wang, S. - See Wilson. B. et al.

Weetman, G. - Distinctly Canadian silviculture and forest management 441

Weingartner, D.H. - See Rice, J.A. et al.

Weingartner, D.H. - See Rice, J.A. et al.

Weisgerber, H. and Y. Han. - Diversity and breeding potential of

poplar species in China

Whitlaw, H. - See Sabine, D.L.

Williams, J. - See Bull, G. et al.

Willick, M.L. - Forest sustainability: Ontario combines science,

policy and consensus

Wilson, B., B. Stennes, S. Wang and L. Wilson. - Secondary

manufacturing in British Columbia: Structure, significance and trends 301

Wilson, B. and L. Wilson. - An economic perspective on clearcut

harvesting

Wilson, B., T. Takahashi and I. Vertinsky. - The Canadian commercial

forestry perspective on certification: National survey results

Wilson, L. - See Wilson B.

Wilson, L. - See Wilson. B. et al.

Winters, J.A. - See Lautenschlager, R.A.

Woods, M. - See Penner, M. et al.

Zarnovican, R., J.-M. Lussier et C. Laberge. - Coupe prépatoire et croissance en surface terrière d'une sapiniére de seconde venue à la forêt modèle du Bas-Saint-Laurent, Québec

Zasada, J.C. - See David, A.J. et al.

Zeide, B. - Resolving contradictions in forestry: Back to science 